\title{
First report of downy mildew caused by Bremia lactucae on Gerbera jamensonii in Argentina
}

\author{
S. M. Wolcan \\ Comisión de Investigaciones Científicas de la Provincia de Buenos Aires, CIDEFI, Facultad de Ciencias Agrarias \\ y Forestales, UNLP, 60 y 119, (1900) La Plata, Buenos Aires, Argentina. Email: swolcan@speedy.com.ar
}

\begin{abstract}
In autumn 2007, leaves of Gerbera jamensonii with typical symptoms of downy mildew were collected in Buenos Aires province, Argentina. Based on symptoms and the morphology of the fungus, the pathogen was identified as Bremia lactucae. This is the first report of downy mildew on gerbera in Argentina.
\end{abstract}

Gerbera jamensonii (gerbera, Transvaal daisy) is a perennial ornamental cropped mainly as cut flowers, and also as potted flowering plants. In Argentina, the main cropping area is located in the outskirts of La Plata and Buenos Aires cities (Buenos Aires province), which are located in the main horti-floricultural region of the country. In recent years gerbera cultivation has spread out to other provinces. In autumn 2007, a downy mildew infection was observed on plants of gerbera var. Avant Garde cultivated in greenhouses. Symptoms began as irregularly shaped yellow discoloration on the upper surface of the leaf, later turning light to dark brown and reaching $5 \mathrm{~cm}$ long, vein delimited. The lesions were localised to the leaf margins or the centre of the lamina (Fig. 1). The typical white greyish sign of downy mildew was observed on the lower surface of the leaves on necrotic tissues or surrounding them (Fig. $2 a$ and $b$, respectively). As the infection progressed, lesions coalesced and in some cases necrotic tissues dried up and cracked (Fig. 2a).

Pathogen description: the hyaline conidiophores emerged through stomata and measured 475-625 × 10-13 $\mu \mathrm{m}$ (the length of the conidiophores up to the first branch measured 275-450 $\mu \mathrm{m})$. The conidiophores were dichotomously branched, and had branch tips ending in swollen vesicles $(7-9 \mu \mathrm{m})$ bearing 3-5 sterigmata $(3.7-7.4 \mu \mathrm{m})$. Conidia were pale olivaceous in colour and ovoid to globose in shape $(22.2-25.9 \times$ $18.5-25.9 \mu \mathrm{m})$ (Fig. $3 a$ and $b$ ). On the basis of symptoms and morphology the pathogen was identified as Bremia lactucae (Shin and Choi 2000). The dried specimen examined is deposited in the Herbarium of the Instituto Spegazzini (http://www.fcnym. unlp.edu.ar/institutos/spegazzini/) with the accession number LPS 48252.

In order to fulfil Koch's postulates, a pathogenicity test was conducted. Sections of infected leaves were gently pressed and attached onto healthy leaves and the whole plants were covered with plastic bags for $48 \mathrm{~h}$ and kept at $18-22^{\circ} \mathrm{C}$. Non-inoculated control plants were maintained under the same conditions in
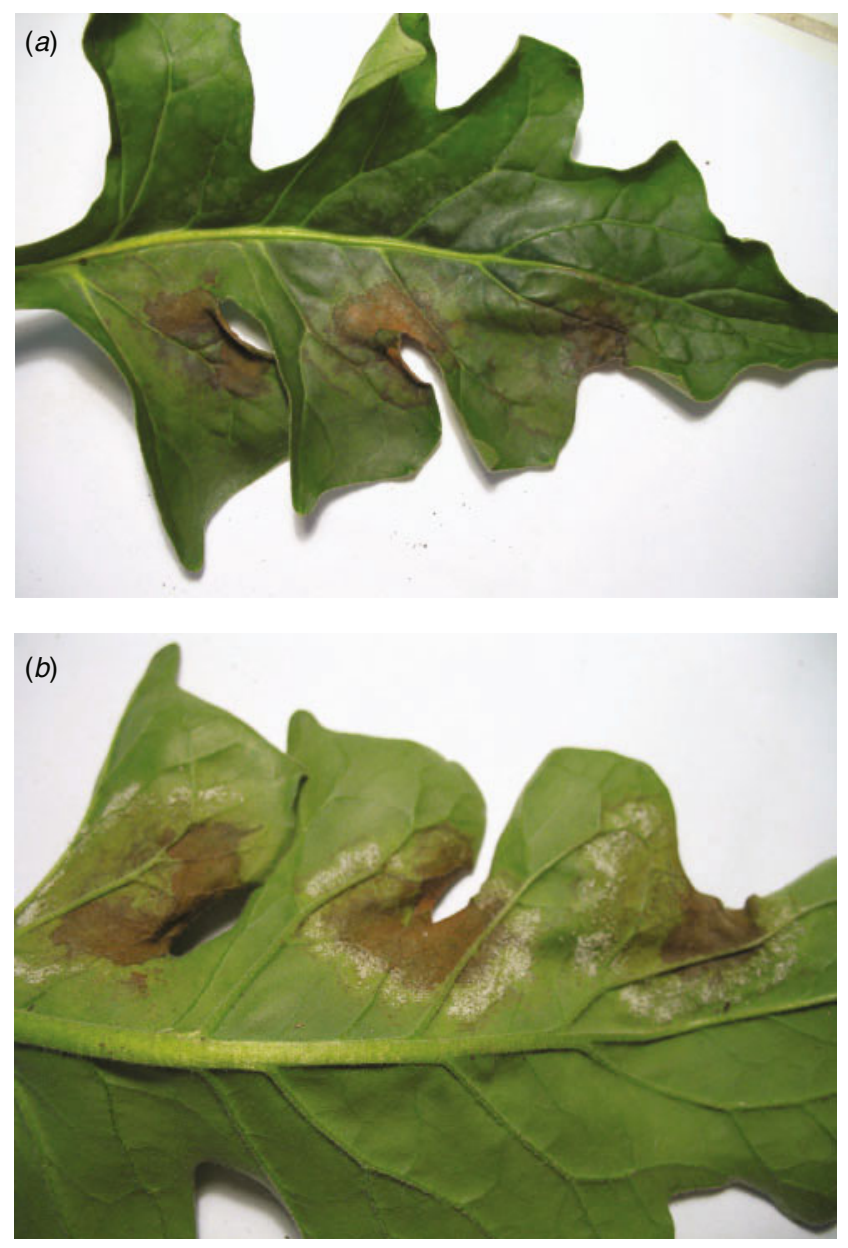

Fig. 1. Symptoms of downy mildew on the upper $(a)$ and lower surfaces (b) of a gerbera leaf. 

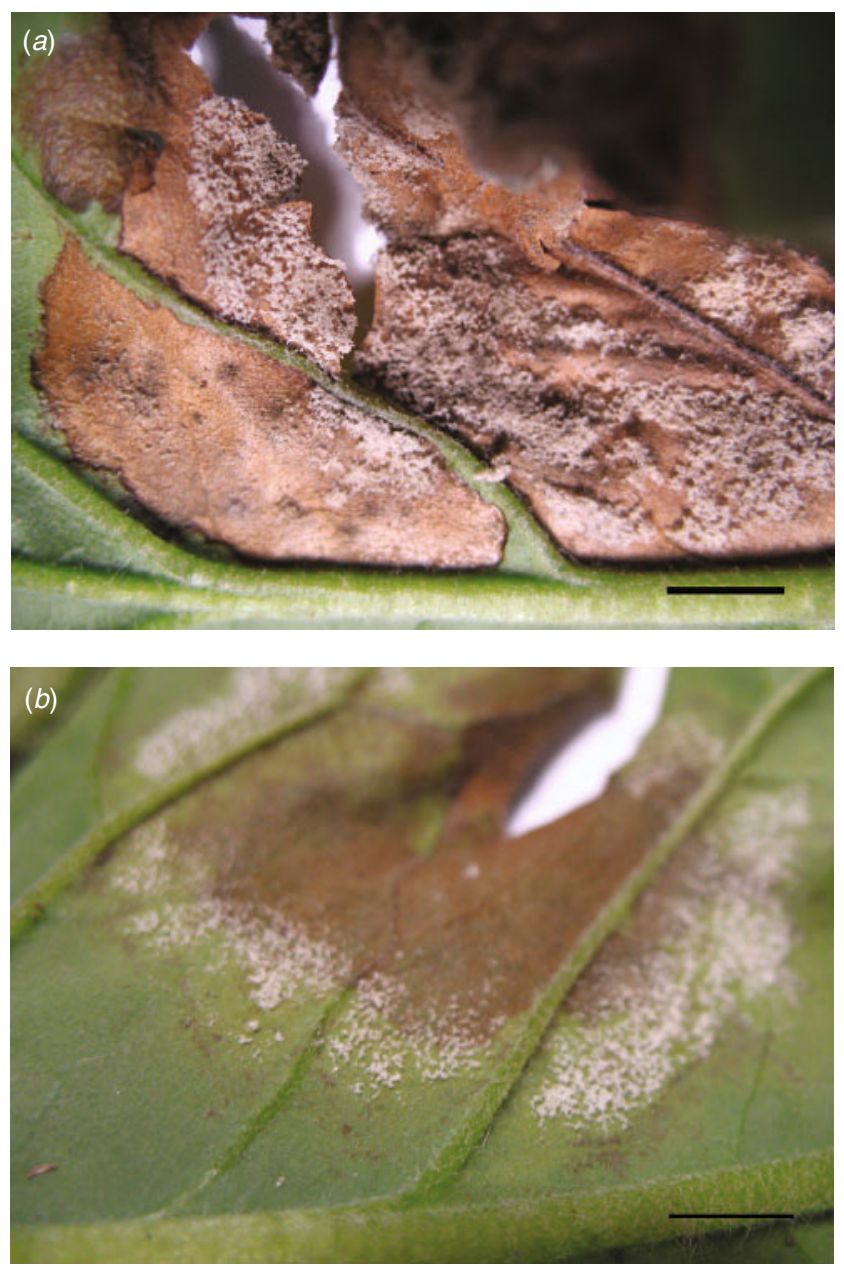

Fig. 2. Signs of the disease (conidia and conidiophores) on necrotic cracked tissues on the lower surface of the leaf, bar $=1 \mathrm{~cm} \mathrm{(a)}$, and on asymptomatic tissues surrounding the necrotic lesion on the lower surface of the leaf, bar $=1 \mathrm{~cm}(b)$.

another compartment of the greenhouse. After 10 days downy mildew leaf symptoms developed on inoculated plants and the controls remained asymptomatic. Microscopic examination of the conidiophores confirmed that the disease-causing agent was identical to that of the starting material.

Downy mildew on gerbera (Astereae) caused by Bremia sp. has been recorded previously in Brazil (Mendes et al. 1998), Germany (Schikedanz 1993) and in Poland (caused by B. lactucae) (Farr and Rossman 2010). The disease on gerbera is also caused by Plasmopara sp. in USA (Farr and Rossman 2010).

Bremia lactucae causes downy mildew on a wide number of hosts belonging to several botanical families, including Asteraceae (Crute and Dixon 1981). Kenneth and Palti (1984) compiled information about the relationship between Bremia and Asteraceae and observed that Bremia affects mostly hosts of the Cynareae and Lactuceae tribes and only two genera of Astereae. In Argentina, B. lactucae has been reported affecting three members of the Asteraceae family: lettuce (Lactuaceae) (Wolcan et al. 2010), escarole (Cichorium endivia, Lactuaceae)
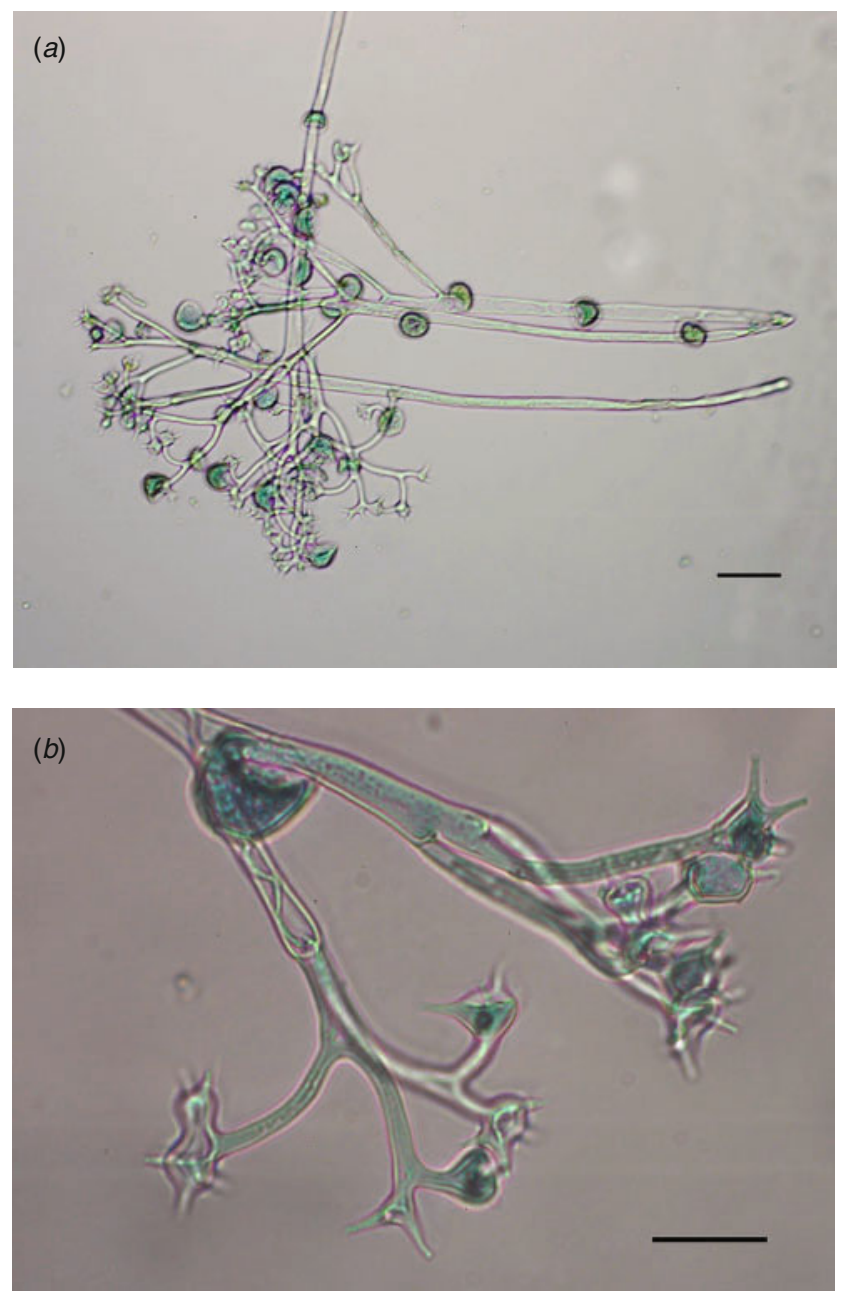

Fig. 3. Conidia and conidiophores, bar $=50 \mu \mathrm{m}(a)$ and vesicles and sterigmata, $b a r=25 \mu \mathrm{m}(b)$ of Bremia lactucae.

(Goldemberg and Castronovo 1960) and most recently on artichoke (Cynareae) (Carranza et al. 2001). Downy mildew caused by $B$. lactucae is an endemic disease in lettuce, which is cultivated in the same area as artichoke, escarole and gerbera but was not noted on gerbera in this region until 2007, and was not confirmed until now. As such, this is the first report of downy mildew on G. jamensonii in Argentina.

\section{References}

Carranza M, Larran S, Alippi H (2001) First report of artichoke downy mildew caused by Bremia lactucae in Argentina. Plant Disease 85, 446. doi:10.1094/PDIS.2001.85.4.446D

Crute IR, Dixon GR (1981) Downy mildew disease caused by the genus Bremia Regel. In 'The Downy Mildews'. (Ed. DM Spencer) pp. 421-460. (Academic Press: London)

Farr DF, Rossman AY (2010) Fungal Databases, Systematic Mycology and Microbiology Laboratory, ARS, USDA. 10 April 2010, http://nt.ars-grin. gov/fungaldatabases/

Goldemberg JB, Castronovo AM (1960) Enfermedades de las hortalizas observadas en la aregión litoral (norte de la provincia de Buenos Aires). IDIA 150, 51-62. 
Kenneth R, Palti J (1984) The distribution of downy and powdery mildews and of rusts over the tribes of Compositae (Asteraceae). Mycologia 76, 705-718. doi: $10.2307 / 3793228$

Mendes MAS, da Silva VL, Dianese JC, Ferreira MASV, Santos CEN, Gomez Neto E, Urben AF, Castro C (1998) 'Fungos em plantas no Brasil.' (Embrapa - SPI/Embrapa-Cenargen: Brasilia) 555 pp.

Schikedanz F (1993) Downy mildew on gerbera. Zeitschrift fur Pflanzenkrankheiten und Pflanzenschutz 100, 662-664.
Shin HD, Choi YJ (2000) 'Peronosporaceae of Korea.' (National Institute of Agricultural Science and Technology: Suwon, Korea) 166 pp.

Wolcan S, Docampo D, Nome F (2010) Enfermedades de Lactuca sativa L. (lechuga). In 'Atlas Fitopatológico Argentino' Vol. 3, No. 2. (Eds SF Nome, DM Docampo, LR Conci) Córdoba, Argentina. 20 May 2010. http://www.fitopatoatlas.org.ar/default.asp?hospedante $=713$

Manuscript received 23 June 2010, accepted 27 August 2010 